\title{
Replacing protein supplements in barley-based diets for growing pigs with free lysine and methionine
}

\author{
MATTI NÄSI \\ University of Helsinki, Department of Animal Husbandry, \\ SF-007I0 HELSINKI, Finland
}

\begin{abstract}
Protein metabolism and utilization, and performance were examined in pigs kept on diets with two protein levels, 15 and $17 \%$ crude protein (cp), and supplementation with free L-lysine and DL-methionine. In the $5 \times 5$ Latin square balance trial, 15 and $17 \% \mathrm{cp}$ diets were fed with and without supplementation with $2 \mathrm{~g}$ lysine $/ \mathrm{kg}$ feed and one $15 \mathrm{cp}$ diet with both lysine and $0.7 \mathrm{~g}$ methionine. The diets had 120 and $136 \mathrm{~g}$ DCP/FU, lysine 7.8, 9.4 and $11.0 \mathrm{~g} / \mathrm{kg}$ and sulphur amino acids $4.4,5.0$ and $5.1 \mathrm{~g} / \mathrm{kg}$. Nitrogen retention was $13 \%$ higher on the $17 \% \mathrm{cp}$ diet than on the $15 \% \mathrm{cp}$ diet $(\mathrm{P}>0.05)$. The lysine supplementation improved $\mathrm{N}$ retention by $4.3 \%$ on the $15 \% \mathrm{cp}$ diet and supplementation with the two amino acids improved it by $2.5 \%(\mathrm{P}>0.05 \%)$. Urinary urea excretion on the $17 \% \mathrm{cp}$ diet was $17-12 \%$ higher than on unsupplemented $15 \% \mathrm{cp}$ diet, and on the diets with amino acid supplementation it was $7-8 \%$ lower $(\mathrm{P}<0.05)$ than on the diets without.

In the first feeding trial with 500 pigs, the higher-protein diet gave $7.4 \%$ better daily gains. The diet with $15 \%$ cp supplemented with lysine gave only $2.3 \%$ better gains than the basal $15 \% \mathrm{cp}$ diet. The difference in feed conversion efficiency (FCE) between protein levels was statistically significant $(\mathrm{P}<0.05)$. The second feeding trial was a comparison of $17 \%$ and $15 \% \mathrm{cp}$ diets in which the lysine and sulphur amino acid levels hąd been equalized by supplementing the $15 \% \mathrm{cp}$ diet with lysine and methionine. The pigs were fed on a grower diet with $18 \% \mathrm{cp}$ to $50 \mathrm{~kg}$ live weight and afterwards the experimental diets were fed separately to the gilts and castrates. The pigs grew similarly on the two diets, 783 vs. $780 \mathrm{~g}$ daily. The FCE was better on the lower-protein diet and lower in the gilts then the castrates. The gilts gave better carcase quality than the castrates and the lower-protein diet tended to give better carcase quality. The rather poor response to supplemental free amino acids in the present study seems to indicate limitation of inadequate supply of other amino acid.
\end{abstract}

Index words: Protein nutrition, synthetic amino acids, pig feeding, nitrogen balance

\section{Introduction}

Pig formulas are normally based on grain and the diets are supplemented with protein sources to increase the total protein content and to counteract any essential amino acid deficiency. In experiments (Alaviuhrola 1981), in which the crude protein level is raised 
progressively and the protein comes from conventional sources, it is likely that the response to protein which is measured is really a response to lysine. This is commonly the most limiting amino acid for pigs on a barley-based diet (Fuller et al. 1979). When the diet is supplemented with protein concentrate, with the aim of reaching levels of lysine and threonine optimal for protein synthesis, the amounts of other amino acids may become excessive (TAYLOR et al. 1979). The digestible crude protein which the pig cannot utilize for protein deposition is mainly transformed into urea and excreted in the urine, raising energy costs and reducing protein efficiency (FULLER et al. 1979).

The restrictions now placed on the import of feed protein into Finland and the desirability of developing domestic protein sources have increased interest in formulation of animal diets on an amino acid basis, using synthetic amino acids to ensure efficient protein utilisation. The growth rate, feed conversion efficiency and leanness of Finnish pigs have been improved considerably. Whether the protein and lysine requirements have been altered by the increased potential for protein deposition now requires to be investigated.

The objective of the present study was to examine the protein utilization the daily gain and carcase quality of growing pigs when part of their protein supplements was replaced with synthetic lysine and methionine.

\section{Materials and methods}

The experimental diets were barley-based and supplemented with soybean meal and fish meal $(4+1)$ to give crude protein levels of 15 and $17 \%$. Synthetic L-lysine $\mathrm{HCl}$ alone or lysine and DL-methionine together were added to some diets, to give the same amino acid levels as were supplied by the protein supplements in others. One of the $17 \% \mathrm{cp}$ diets was had a higher level of lysine. The composition of the diets used in the balance trial and an analysis of their ingredients are shown in Table 1. The data on the complete feeds used in the feeding trials are shown in Table 2 .

The nitrogen balance trial was carried out with six castrated Landrace $x$ Large White pigs weighing $38-80 \mathrm{~kg}$, the design being a $5 \times 5$ Latin square. One pig was kept on a proteinfree diet, based on barley starch $(84.5 \%)$ and supplemented with barley straw (10\%), butter $(2.5 \%)$ and a mineral mixture $(3 \%)$, to measure metabolic faecal nitrogen and urinary endogenous nitrogen. The experimental animals were housed individually in metabolic cages, which allowed separate quantitative collection of urine and faeces. These were collected twice daily and representative samples were frozen and stored until analysis. The pigs were fed twice daily according to a standard scale based on the live weight (SALo et al. 1982). The diet was mixed with water $(1+2$ $w / v)$ and water was given after feeding. The feed spillage was collected and substracted from the ration. The daily rations in the different periods were $1.6-2.8 \mathrm{~kg}$. The pigs were weighed before and after each period. The details of the procedure are the same as described by NÄsı (1984).

The two growth trials were performed on a commercial pig farm (T. Ahonranta, Loimaa) wtih 500 pigs in each experiment. The pigs were assigned at random to the different feeds, the variations in starting weight between the groups being kept as small as possible. Twelve pigs were placed in each pen, there were ten replicates of each of the four treatments and the animals were fed on the same diet throughout the experimental period. In the second trial rearing methods were compared and the gilts and castrates were kept either in separate pens or together. In this trial all the pigs were fed the same grower diet, $18 \% \mathrm{cp}$, to $50 \mathrm{~kg}$ live weight, after which they received one of the two experimental diets. In the second trial the number of replicates was $6-7$ per treatment. In the trials the pigs were fed according to a restricted feeding regimen and feeding was the same for the two sexes (SAlo et al. 1982). 
Table 1. Composition and analyses of the diets and ingredients used in the balance trial.

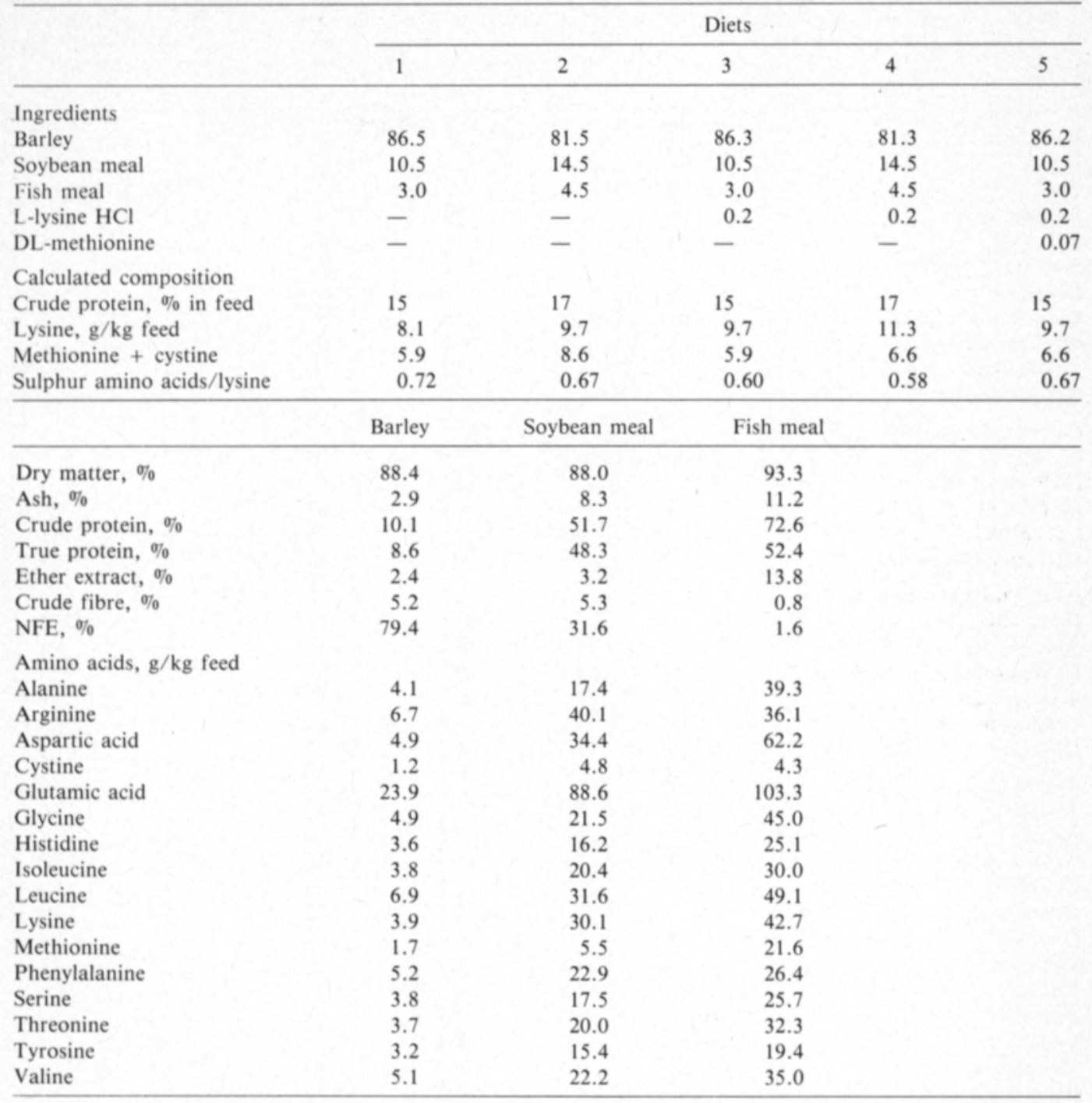

The chemical analyses of the feeds and faeces were performed according to the official procedures and the other analyses were the same as described by Näsı (1984). The data were treated by the analysis of variance and the differences between the treatment means were tested by the Tukey test (STEEL and TorRIE 1960). In the second growth trial, covariance was applied to eliminate the effect of the difference in starting weights between treatments.

\section{Results and discussion}

The experimental diets used in the balance trial had slightly lower protein contents, 14.5 and $16.9 \%$, than estimated (15.0 and $17.0 \%)$, because the barley proved to have a rather low crude protein (CP) content (10.1\% of DM). The digestible crude protein contents of the diets were calculated to be 120 and $136 \mathrm{~g} /$ feed unit (FU), and thus the diet with the lower cp value did not satisfy the protein requirements 
Table 2. Composition and analyses of the experimental diets used in the feeding trials.

\begin{tabular}{|c|c|c|c|c|c|c|}
\hline & \multicolumn{4}{|c|}{ Trial 1} & \multicolumn{2}{|c|}{ Trial 2} \\
\hline & \multicolumn{4}{|c|}{ Treatments } & \multicolumn{2}{|c|}{ Treatments } \\
\hline & 1 & 2 & 3 & 4 & 5 & 6 \\
\hline \multicolumn{7}{|l|}{ Ingredients, \% } \\
\hline Barley & 78.5 & 78.5 & 82.0 & 82.0 & 57.7 & 61.7 \\
\hline Oats & - & - & - & - & 20.0 & 20.0 \\
\hline Soybean meal & 13.0 & 13.0 & 11.0 & 11.0 & 12.8 & 10.5 \\
\hline Fish meal & 5.0 & 5.0 & 3.0 & 3.0 & 5.0 & 3.0 \\
\hline Feed fat & & & & & 1.0 & 1.0 \\
\hline Limestone flour & 1.5 & 1.5 & 1.5 & 1.5 & 1.3 & 1.3 \\
\hline Dicalcium phosphate & 1.0 & 1.0 & 1.5 & 1.5 & 1.2 & 1.3 \\
\hline Min. vit. mix. & 0.8 & 1.0 & 0.8 & 1.0 & 1.0 & 1.0 \\
\hline L-lysine- $\mathrm{HCl}$ & 0.2 & - & 0.2 & - & - & 0.151 \\
\hline DL-methionine & - & - & - & - & - & 0.07 \\
\hline \multicolumn{7}{|l|}{ Calculated nutrients } \\
\hline Crude protein, $\%$ & 17.0 & 17.0 & 15.0 & 15.0 & 17.0 & 15.0 \\
\hline DCP, $\%$ of feed & 13.5 & 13.5 & 12.0 & 12.0 & 13.5 & 12.0 \\
\hline $\mathrm{Kg}$ feed/FU & 1.03 & 1.03 & 1.03 & 1.03 & 1.02 & 1.02 \\
\hline Lysine, $\%$ & 1.05 & 0.90 & 0.90 & 0.75 & 0.93 & 0.93 \\
\hline Methionine + cystine & 0.50 & 0.50 & 0.42 & 0.42 & 0.53 & 0.53 \\
\hline \multicolumn{7}{|l|}{ Analysed composition, in DM } \\
\hline Dry matter, \% & 87.4 & 87.6 & 87.6 & 87.6 & 88.7 & 88.7 \\
\hline Ash, $\%$ & 6.0 & 5.9 & 6.1 & 6.3 & 6.1 & 5.8 \\
\hline Crude protein, \% & 19.2 & 18.8 & 16.9 & 16.7 & 19.0 & 17.1 \\
\hline Ether extract, \% & 3.1 & 3.0 & 2.7 & 2.6 & 4.6 & 4.3 \\
\hline Crude fibre, $\%$ & 5.1 & 5.8 & 5.4 & 4.8 & 5.1 & 5.4 \\
\hline NFE, $\%$ & 67.2 & 67.0 & 69.6 & 69.9 & 65.2 & 67.4 \\
\hline \multicolumn{7}{|l|}{ Amino acids, $\mathrm{g} / \mathrm{kg}$ feed } \\
\hline Alanine & 7.2 & 7.0 & 6.1 & 6.2 & 8.2 & 7.2 \\
\hline Arginine & 8.5 & 8.2 & 7.1 & 7.3 & 10.8 & 10.4 \\
\hline Aspartic acid & 15.8 & 15.8 & 13.4 & 13.4 & 14.5 & 13.5 \\
\hline Cystine & 3.6 & 3.4 & 3.5 & 3.6 & 3.3 & 3.1 \\
\hline Glutamic acid & 30.4 & 28.3 & 28.0 & 28.5 & 30.4 & 29.0 \\
\hline Glycine & 7.5 & 7.1 & 6.4 & 6.3 & 8.0 & 7.1 \\
\hline Histidine & 3.5 & 3.5 & 3.0 & 3.0 & 3.8 & 3.6 \\
\hline Isoleucine & 5.4 & 5.4 & 4.7 & 4.7 & 6.7 & 6.0 \\
\hline Leucine & 10.8 & 10.8 & 9.5 & 9.8 & 12.3 & 11.4 \\
\hline Lysine & 10.5 & 9.0 & 8.9 & 7.7 & 8.7 & 8.8 \\
\hline Methionine & 2.1 & 2.2 & 1.7 & 1.9 & 1.5 & 2.6 \\
\hline Phenylalanine & 6.8 & 7.0 & 5.9 & 6.2 & 7.9 & 7.2 \\
\hline Proline & 11.3 & 11.6 & 10.9 & 11.8 & 11.6 & 11.1 \\
\hline Serine & 8.1 & 7.9 & 7.1 & 7.2 & 8.2 & 7.3 \\
\hline Threonine & 6.7 & 6.6 & 5.7 & 5.8 & 6.6 & 5.8 \\
\hline Tyrosine & 3.7 & 3.4 & 3.0 & 3.0 & 5.5 & 5.1 \\
\hline Valine & 6.7 & 6.9 & 6.1 & 6.2 & 8.6 & 7.6 \\
\hline
\end{tabular}

of growing lean-type pigs on a restricted feeding regimen. The amino acid contents of the diets were calculated to be also a little lower than intended, $0.78,0.94$ and $1.10 \%$ for lysine (LYS) $(0.81,0.97$ and $1.13 \%)$ and $0.44,0.50$ and $0.51 \%$ for methionine and cystine $(0.59$ and $0.66 \%)$. The low values for sulphuric amino acids (SAA) may partly be an analytical error, because these are easily destroyed when the samples are prepared. The threonine contents were 0.63 and $0.74 \%$ (Table 1). The amino acid requirements presented for growing pigs are $0.85-0.9 \%$ for lysine, $0.55-0.6 \%$ for SAA and $0.5 \%$ for threonine (SAlo et al. 1982). The fish meal in the present study had a low lysine content, 6.3 
Table 3. Nitrogen balance and protein utilisation in pigs on diets with different protein contents and supplemented with synthetic amino acids.

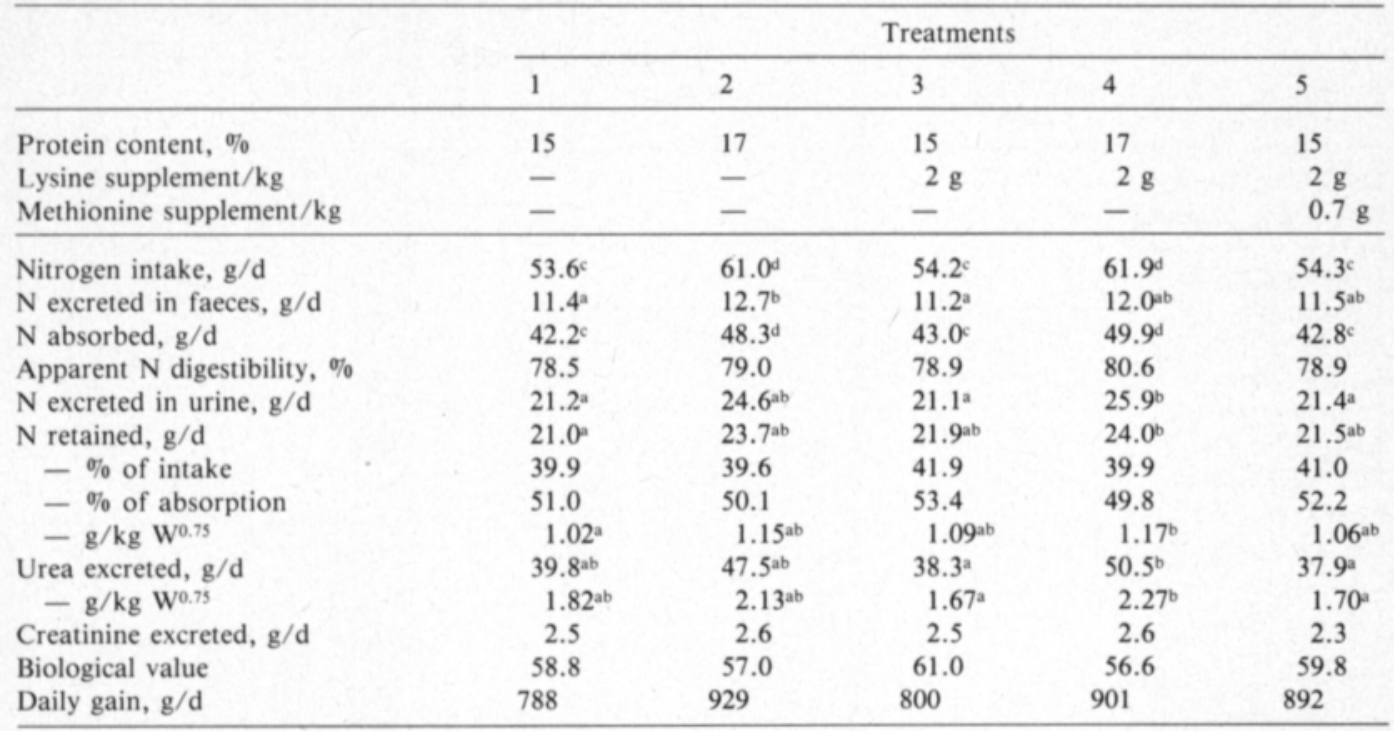

Means with different letters were significantly different $(\mathrm{a}, \mathrm{b}, \mathrm{P}<0.05 ; \mathrm{c}, \mathrm{d}, \mathrm{P}<0.01)$.

$\mathrm{g} / 16 \mathrm{~g} \mathrm{~N}$. In the growing pig diets, the analysis values were close to the estimated values (Table 2), except that the crude protein contents were a little low and the SAA contents of the diets in growth trial 1 were a little higher than estimated.

The crude protein intake on the $17 \% \mathrm{cp}$ diet was significantly higher $(\mathrm{P}<0.01)$ than on the $15 \% \mathrm{cp}$ diet (Table 3). The apparent digestibilities of nitrogen were slightly higher on the diet with a higher protein content $(\mathrm{P}>0.05)$, which indicates that the protein supplements were more digestible than barley protein. $\mathrm{N}$ excretion in the urine was higher on the diets containing more protein $(\mathrm{P}<0.05)$, which indicates that the protein supply was excessive or the amino acids not properly balanced. $\mathrm{N}$ retention was $13 \%$ better in pigs on the $17 \% \mathrm{cp}$ diet than on the $15 \%$ cp diet (23.7 vs. $21.0 \mathrm{~g} \mathrm{~N} / \mathrm{d}$ ). Lysine supplementation of $2 \mathrm{~g} / \mathrm{kg}$ feed on the $15 \%$ cp diet improved nitrogen retention by $4.3 \%$ ( $\mathrm{P}>0.05$ ). When Low and PITTMAN (1979) supplemented a control diet containing $7 \mathrm{~g} / \mathrm{kg}$ feed with $1 \mathrm{~g} / \mathrm{kg}$ L-lysine, nitrogen retention increased from 20.3 to $23.1 \mathrm{~g} / \mathrm{d}$. In the present study the comparatively low response to supplemental lysine indicated that an essential amino acid or possibly the supply of nonessential amino acids was limiting for protein synthesis. Supplementation of the diet with both lysine and methionine, however, increased nitrogen retention by only $2.5 \%$ of the level on the basal diet. Supplementation with methionine improved nitrogen retention only slightly, but the diets proved to be deficient in this respect. Increased response of SAA in growing pig diets up to $0.60 \%$ in feed have been found when one third originated from synthetic methionine (BERENDE and Bertram 1983). The only statistically significant difference in the nitrogen balance was found between the $15 \% \mathrm{cp}$ diet and the $17 \%$ diet supplemented with LYS $(\mathrm{P}>0.05)$. The nitrogen retention calculated as $\mathrm{g} / \mathrm{kg} \mathrm{W}^{0.75}$ accorded with the daily nitrogen retention values (Table 3 ). For the pig on the proteinfree diet the measured faecal metabolic nitrogen excretion was $1.43 \mathrm{~g} \mathrm{~N} / \mathrm{kg} \mathrm{DM}$ intake and the urinary endogenic $\mathrm{N}$ excretion was 0.099 
Table 4. Performance of growing pigs on diets with different protein content and supplemented with L-lysine $\mathrm{HCl}$ in trial 1 .

\begin{tabular}{|c|c|c|c|c|}
\hline Diet no. & 1 & 2 & 3 & 4 \\
\hline Protein \% & 17 & 17 & 15 & 15 \\
\hline Lysine suppl. & $2 \mathrm{~g}$ & - & $2 \mathrm{~g}$ & - \\
\hline No. of pigs at start & 126 & 125 & 126 & 126 \\
\hline No. of pigs at end & 124 & 125 & 126 & 124 \\
\hline Mortality, \% & 1.6 & 0 & 0 & 1.6 \\
\hline Initial weight, $\mathrm{kg}$ & 23.6 & 24.2 & 23.8 & 24.0 \\
\hline Final weight, kg & 101.7 & 103.7 & 101.2 & 99.6 \\
\hline Carcase weight, $\mathrm{kg}$ & 74.4 & 74.7 & 73.8 & 73.0 \\
\hline Slaughter loss, $\%$ & 26.8 & 28.0 & 27.1 & 26.8 \\
\hline Days in experiment & 114.8 & 114.7 & 116.2 & 116.1 \\
\hline Daily gain, g & 680 & 699 & 666 & 651 \\
\hline $\mathrm{FCE} \mathrm{kg} / \mathrm{kg}$ gain & $2.98^{c}$ & $2.99^{\circ}$ & $3.12^{\mathrm{d}}$ & $3.17^{\mathrm{d}}$ \\
\hline Feed $\mathrm{kg} / \mathrm{d}$ & $2.02^{\mathrm{a}}$ & $2.09^{\mathrm{b}}$ & $2.08^{\mathrm{b}}$ & $2.06^{\mathrm{ab}}$ \\
\hline \multicolumn{5}{|l|}{ Carcase grading, } \\
\hline$E+, \%$ & 14.5 & 18.4 & 11.9 & 8.9 \\
\hline E & 30.7 & 24.8 & 23.0 & 19.4 \\
\hline I & 41.9 & 48.8 & 53.2 & 58.9 \\
\hline I- & 10.5 & 7.2 & 11.9 & 8.9 \\
\hline Withdrawal & 2.4 & 0.8 & 0 & 4.0 \\
\hline
\end{tabular}

Means with different letters were statistically significant $(a, b \quad P<0.05, c, d, P<0.01)$.

$\mathrm{g} \mathrm{N} / \mathrm{kg} \mathrm{W}^{0.75}$. The values found here are in accordance with those reviewed by CARR et al. (1977).

Urinary urea excretion on the $17 \% \mathrm{cp}$ diets was $17-12 \%$ higher than on the unsupplemented $15 \% \mathrm{cp}$ diet and on the diets with amino acid supplementation it was $7-8 \%$ lower $(\mathrm{P}<0.05)$ than on the diets without. The urea excreted in the urine of the pig on the protein-free diet was only $0.9 \mathrm{~g} / \mathrm{d}$. The quantity of urinary urea, which is the major metabolite of nitrogen excretion in the pig, is greatly influenced by the protein quality and the amino acid balance (BROWN and CLINE 1974). Lysine supplementation improved the biological value of the diet protein by $2.2 \%$ units and the lysine + methionine supplements given together improved it by $1.0 \%$ units. Fuller et al. (1979) have shown that supplementation of barley with lysine and threonine increased the biological value of barley protein from 51 to 86 , and histidine supplementation further increased the biological value to 93 . The daily gains on the diets with a lower protein content were ca. $100 \mathrm{~g}$ lower, than on the $17 \mathrm{cp}$ diets, except in the case of the $15 \% \mathrm{cp}$ diet supplemented with both the synthetic amino acids, which gave the same daily gain as the diets with $17 \% \mathrm{cp}$. The response of pigs to supplementation of low protein diets with essential amino acids can depend on several factors (Low 1980). Additions of single amino acids should evoke a positive response only if the amino acid is first limiting (Fuller et al. 1979). Here supplementation of a deficient protein supply with synthetic amino acids gave poorer results than expected from the amino acid figures of the supplemented diets, which indicated some essential amino acid deficiency or that the protein supply was inadequate, since the pigs at the higher protein level performed better. Utilization of the high levels of synthetic amino acids may have been impaired by unequal rates of absorption of protein derived and synthetic amino acids, as suggested by BAT. terham (1984). However, Partridge et al. (1985) did not find any differences in $\mathrm{N}$ use when pigs were fed twice a day or more frequently with diets supplemented with free lysine.

Table 4 shows the performance of the pigs 
Table 5. Performance of growing pigs on diets with different protein content supplemented with $\mathrm{L}$-lysine $\mathrm{HCl}$ and DL-methionine when the sexes were reared together and separately in trial 2.

\begin{tabular}{|c|c|c|c|c|c|c|c|c|}
\hline \multirow[t]{2}{*}{$\begin{array}{l}\text { Treatments } \\
\text { Rearing }\end{array}$} & \multicolumn{3}{|c|}{ Diet $5(17 \% \mathrm{CP})$} & \multicolumn{3}{|c|}{$\begin{array}{c}\text { Diet } 6(15 \% \mathrm{CP}+ \\
\text { Lys.Met.) }\end{array}$} & \multicolumn{2}{|c|}{$\begin{array}{l}\text { Significance } \\
\text { of difference }\end{array}$} \\
\hline & $\begin{array}{l}\text { Gilts + } \\
\text { Castrat }\end{array}$ & Gilts & $\begin{array}{c}\text { Castra- } \\
\text { tes }\end{array}$ & $\begin{array}{l}\text { Gilts + } \\
\text { Castrat }\end{array}$ & Gilts & $\begin{array}{c}\text { Castra- } \\
\text { tes }\end{array}$ & Diets & Groups \\
\hline No. of pigs at start & 84 & 84 & 84 & 96 & 72 & 84 & & \\
\hline No. of pigs at end & 83 & 84 & 83 & 96 & 70 & 84 & & \\
\hline Mortality, $\%$ & 1.2 & 0 & 1.2 & 0 & 2.8 & 0 & & \\
\hline Initial weight, kg & 48.4 & 53.6 & 53.3 & 53.1 & 54.3 & 53.4 & & \\
\hline Final weight, kg & 102.0 & 106.8 & 107.2 & 107.4 & 107.0 & 106.7 & & \\
\hline Carcase weight, $\mathrm{kg}$ & 73.8 & 77.9 & 77.2 & 76.3 & 78.2 & 76.7 & & \\
\hline Slaughter loss, \% & 27.2 & 27.1 & 28.0 & 29.0 & 26.9 & 28.1 & & \\
\hline Days in experiment & 73.0 & 65.1 & 67.5 & 68.9 & 66.5 & 66.6 & & \\
\hline Daily gain, $\mathrm{g}$ & 755 & 811 & 784 & 777 & 767 & 796 & NS & NS \\
\hline $\mathrm{FCE} \mathrm{kg} / \mathrm{kg}$ gain & 3.36 & 3.06 & 3.27 & 3.21 & 3.07 & 3.19 & NS & $\mathrm{P}<0.01$ \\
\hline Feed kg/d & 2.53 & 2.48 & 2.56 & 2.53 & 2.35 & 2.53 & $\mathrm{P}<0.05$ & $\mathrm{P}<0.01$ \\
\hline \multicolumn{9}{|l|}{ Carcase grading, } \\
\hline $\mathrm{E}+, \%$ & 27.7 & 38.1 & 7.2 & 25.0 & 41.4 & 11.9 & & \\
\hline E & 19.3 & 28.6 & 20.5 & 22.9 & 28.6 & 25.0 & & \\
\hline I & 41.0 & 33.3 & 61.4 & 45.8 & 28.6 & 53.6 & & \\
\hline $\mathrm{I}-$ & 12.0 & 0 & 10.8 & 6.3 & 1.4 & 9.5 & & \\
\hline
\end{tabular}

in the trial 1 , on diets with different protein levels, 15 and $17 \%$, and supplemented with lysine. The overall growth of the pigs in this experiment was moderate, $650-700 \mathrm{~g}$ daily. On the diet containing $17 \% \mathrm{cp}$, the daily gain was $7.4 \%$ better than on the diet with $15 \%$ cp. Supplementation of the $15 \% \mathrm{cp}$ diet with lysine improved the gain by only $2.3 \%$ (P > 0.05 ). The lower-protein diet was rather deficient as a feed for the total growing period, $25-100 \mathrm{~kg}$ of live weight, and lysine supplementation alone could not improve the performance. There was a statistically significant difference in feed conversion efficiency $(\mathrm{P}<$ $0.01)$ between the diets with different protein levels. The difference caused by lysine supplementation was quite small. Throughout the experiment, the feed intake was unusually low, averaging $2.02-2.09 \mathrm{~kg} / \mathrm{d}$, and the pigs receiving the diet with $17 \% \mathrm{cp}$ supplemented with lysine consumed significantly less than the other groups $(\mathrm{P}<0.05)$. The carcase quality of the pigs on the higher protein diets tended to be slightly better, grades E + and $\mathrm{E}$ were more frequent in these groups.

Table 5 presents data on the performance of the pigs in trial 2 , in which a $17 \% \mathrm{cp}$ diet was compared with a $15 \% \mathrm{cp}$ diet supplemented with synthetic amino acids to the same lysine and methionine + cystine level as the higher-protein diet. The pigs were kept on the same grower diet to $50 \mathrm{~kg}$ live weight and then swiched to one of the two experimental diets. The pigs in group 1 had a lower initial weight and the results were calculated by the covariance method, taking into account the longer growth time. The pigs grew similarly on the two diets, 783 vs. $780 \mathrm{~g}$ daily gain $(\mathrm{P}>0.05)$. On the higher protein diet the gilts performed better, but the results were the opposite on the lower-protein amino acid-supplemented diet $(\mathrm{P}>0.05)$. Feed consumption was less on the lower-protein diet $(\mathrm{P}<0.05)$ and less in the gilts $(\mathrm{P}<0.01)$. Feed conversion efficiency was better on the lower-protein diet $(\mathrm{P}<$ $0.05)$ than on the $17 \mathrm{cp}$ diet ( 3.16 vs. 3.23 $\mathrm{kg} / \mathrm{kg}$ gain $)$ and lower in the gilts $(\mathrm{P}<0.01)$ than in the castrates. The gilts gave better carcase quality $(\mathrm{P}>0.05)$ than the castrates and the lower-protein amino acid-fortified diet tended to give better carcase quality also.

It can be concluded that supplementation 
of a low-protein diet for growing pigs with synthetic amino acids improved performance and dietary protein use. In the present study improvement on the free amino acid-supplemented diet was less, than could be expected from the amino acid supply. In these experimental diets in adequate amounts of other amino acids may have limited the utilization of synthetic amino acids as a protein substitute.

Acknowledgements. This study was made possible by the support of the Finnish Sugar Co. Thanks are due to Mr. Ari Kettunen for technical assistance and to Mr. Tuomo Ahoranta for providing the necessary facilities and arranging the care of the experimental animals.

\title{
References
}

Alaviuhrola, T. 1981. Energia- ja valkuaisnormikokeita lihasioilla vuosina 1975-1980. Maatalouden tutkimuskeskus. Sikatalouskoeaseman tiedote 2 .

Batterham, E.S. 1984. Utilization of free lysine by pigs. Pig News Inform. 5: 85-88.

Berende, P.L.M. \& Bertam, H.L. 1983. Sulpur amino acid requirement of young pigs. Z. Tierphysiol., Tierernährg. u. Futtermittelkde. 50: 93-100.

Brown, J.A. \& Cline, T.R. 1974. Urea excretion in the pig: An indicator of protein quality and amino acid requirements. J Nutr. 104: 542-.

Carr, J.R., Boorman, K.N. \& Cole, D.J.A. 1977. Nitrogen retention in the pig. Br. J. Nutr. 37: 143-155.

Fuller, M.F., Livingstone, R.M., Baird, B.A. \& AtKin. son, T. 1979. The optimal amino acid supplementation of barley for the growing pig. 1. Response of nitrogen metabolism to progressive supplementation. $\mathrm{Br}$. J. Nutr.: $321-331$.

Low, A.G. 1980. Amino acid use by growing pigs. Recent advances in animal nutrition. Ed. W. Haresign and D. Lewis. Butterworths. p. 141-156.

\section{SELOSTUS}

\section{Rehuvalkuaisen korvaaminen synteettisillä aminohapoilla kasvavan lihasian ruokinnassa}

\author{
Matti Näsi \\ Helsingin yliopisto, Kotieläintieteen laitos, \\ $00710 \mathrm{Helsinki}$
}

Sulavuus- ja tasekokeessa sekä kahdessa kasvatuskokeessa selvitettiin kahden valkuaistason ( 17 ja $15 \%$ rv) ja synteettisen lysiini- ja metioniinilisäyksen vaikutusta valkuaisen hyvăksikäyttöön ja tuotantotuloksiin lihasikojen ruokinnassa. Eri dieettien ravintoaineiden sulavuudet olivat samanlaisia. Typpitase oli sioilla, jotka sai-

— \& Pittman, R.J. 1979. Responses of growing pigs to practical diet supplemented with amino acids. Anim. Prod. 28: 435-436.

NÃsı, M. 1984. Nutritive value and metabolic effects of whey protein concentrate and hydrolysed lactose for growing pigs. J. Agric. Sci. Finl. 56: 227-238.

PARTridge, I.G., Low, A.G. \& KeAl, H.D. 1985. A note on the effect of feeding frequence of nitrogen use in growing boars given diets with varying levels of free lysine. Anim. Prod. 40: 375-377.

SAlo, M.-L., TUORI, M. \& KIISKInEN, T. 1982. Rehutaulukot ja ruokintanormit. Helsinki. 70 p.

Steel, R.G. \& Torrie, J.H. 1960. Principles and procedures of statistics. New York. 481 p.

TAYlor, A.J., Cole, D.J.A. \& Lewis, D. 1979. Amino acid requirement of growing pigs. 1. Effects of reducing protein level in diets containing high levels of lysine. Anim. Prod. 29: 327-338.

Ms received September 30, 1985

vat $17 \%$ rv dieetissä $13 \%$ korkeampi kuin $15 \%$ rvdieetillă $(23.7$ vs. $21.0 \mathrm{~g} / \mathrm{d})$. Lysiinilisäys $0.2 \%$ dieetissä lisäsi typen pidättymistä $4.3 \%$ ja lysiini ja metioniini tăydennettyină samaan tasoon $17 \%$ rv sisältävăn dieetin kanssa lisăsi $2.5 \% \mathrm{~N}$-tasetta. Korkeammalla valkuaistasolla deaminaatio oli voimakkaampaa ja aminohappoli- 
sảys văhensi urean erittymistä virtsassa $7-8 \%$. Kasvatuskokeessa $17 \%$ rv-dieetillă sikojen lisäkasvu oli $7.4 \%$ parempi kuin $15 \%$ rv saaneilla ja $0.2 \%$ :n lysiinilisäys paransi kasvua $2.4 \%$. Toisessa kasvatuskokeessa aminohappotasapainotetulla $15 \%$ :n seoksella saatiin sama kasvutulos kuin $17 \%$ rv sisăltåvällä seoksella, kun koeseoksia kăytettiin $50 \mathrm{~kg}$ :n elopainosta teurastukseen.

Rehuseos, jossa oli $17 \%$ rv (13.6 \% srv), täytti siko- jen valkuaisentarpeen koko kasvatuskauden ajan, joskin deaminaatio oli suurta. $15 \%: \mathrm{n}(12.0 \%$ srv $)$ valkuaistaso oli riittämătőn joidenkin aminohappojen osalta vaikka lysiiniă ja metioniiniä oli lisătty normien mukaisesti. Synteettisten aminohappojen täydennyksillä saatiin pienempiă vaikutuksia valkuaisen hyvăksikäytőssä ja kasvutuloksissa kuin dieettien pitoisuuksista olisi voinut olettaa. 